\title{
К ВОПРОСУ О ПРОБЛЕМАХ, ПОИСКЕ И ИСТОКАХ ФОРМИРОВАНИЯ В ПОЛИТИЧЕСКОМ ПРОСТРАНСТВЕ НАУЧНОЙ КАТЕГОРИИ «РУССКАЯ ВЛАСТЬ»
}

Аннотация: Автор пытается подойти к освещению такой научной категории, как «русская власть». Основное внимание было уделено осмыслению сущности «русской власти» с точки зрения ее исходного кониепта и зарождения в общественно-политической мысли России дискурса, касающейся данной проблемы. Данная проблема актуальна на сегодняшний день так, как формирование новейтего политического курса страны происходит в достаточно сложных условиях. Для принятия адекватных мер в политике всегда необходимо учитывать, как современные условия, так и прочессы, происходящие в прошлом, а, следовательно, необходимо знать, как формировались те или иные институты власти и как к этой проблеме в разные периоды подходили ученые. Для осмысления того, как формируется та или иная концепция или проблема в политической науке наиболее удобным способом исследования становится сравнительный анализ. Таким образом, научная категория «русская власть» формируется в отечественной политической мысли с начала ХІХ века, вплоть до начала советского периода. Новейшая история страны вновь делает эту тему актуальной и в начале 90-х годов, мы видим ряд выдающихся работ отечественных ученых посвященных этой проблеме.

Ключевые слова: «русская власть», общественно-политическая мысль России, процессуальные свойства, политическая власть, консервативный лагерь, идеи радикализма, идеи либерализма, властецентричность, патернализм, легитимное государственное насилие.

П олитическая практика современной России последних десятилетий в значительной степени реанимировала впервые предпринятую попытку осмысления русской социально-политической мыслью XIX века такого научного концепта, как «русская власть». В частности, первыми попытками анализа властных отношений в России можно считать различные теории таких философов, как П.В.Анненков, К.Д. Кавелин ${ }^{1}$ и др. Однако, само понятие «русская власть», как научная категория, в силу отсутствия в исследованиях глубоких методологических подходов, так и не закрепилось как в отечественном, так и западном научном дискурсе.

\footnotetext{
Более подробно см.: Монографии по русской истории: [рассуждения, критические статьи и заметки К.Д Кавелина] [с портр. авт., биогр. очерком и примеч. проф. Д.А. Корсакова]. - 1897. - XXXII с., 1052 стб., III с., [1] л. портр. [6]. Режим доступа: http://dlib.rsl.ru/01003962389)
}

Нам представляется, что подходы с позиций генезиса, особенностей формирования научного поля и процессуальных свойств властных институтов в России представляют серьезную научно-исследовательскую перспективу в отношении категории «русская власть».

Название феномена «русская власть» было предложено учеными Ю.С. Пивоваровым и А.И. Фурсовым $^{2}$, что послужило в конце XX века началом нового витка исследовательского интереса в истории данной проблемы. Несмотря на уже накопленный в России научно-исследовательский опыт в данном направлении, часть ученых-политологов ${ }^{3}$ все же ис-

\footnotetext{
2 Фурсов А.И, Пивоваров Ю.С. Русская система: генезис, структура, функционирование: (Тезисы и рабочие гипотезы) // Русский исторический журнал. 1998. - Т.1. - № 3. С.184-185

3 Более подробно см.: Ирхин Ю. Российская политология: двадцать или двести лет спустя? // Актуальные вопросы политологии и политики в России. М., 2008.
} 


\section{Внутренний контур национальной безопасности}

ходят из того, что «русская власть» - это комплекс устойчивых и воспроизводящихся в российской политической истории свойств политических режимов. Однако, нам представляется, что такой формальнологический подход не дает полного представления о «русской власти» как научной категории. Прежде всего, потому, что за рамками исследовательского поля остаются процессуальные свойства политической власти в России.

Еще один подход к осмыслению специфических свойств русской власти, как власти, основанной на борьбе патернализма и либеральной традиции, отраженный в работах А.Л.Янова 4 , В.Б.Пастухова, является метафизическим. Он отсылает к категориям политического мифа и также не дает полного ответа на исследовательские вопросы.

Характеристиками феномена «русская власть» часто называют властецентричность и принудительные формы социального взаимодействия, которые несут за собой большую роль легитимного государственного насилия как способа легитимации власти. Подобные черты, по мнению Ю.С Пивоварова и А.И Фурсова, заставляют государство на каждом этапе начинать все сначала, отметая прошлый опыт, создавая тем самым некую цикличность, порождающую парадоксальность действий и зачастую их фактическую неэффективность. ${ }^{5}$ Но несмотря на это, что предыдущий исторический и социальный опыт властью полностью отметается, ситуация не меняется в корне. Существует некая готовая схема действий, переполненная традиционными элементами и последовательностью решений, что и создает ситуацию цикла. При таком характере власти, возможно говорить о некой традиционности и почти ритуальности базовых установок как в обществе, так и во властных структурах. Это положение подтверждается тем, что властецентричность и принудительность форм взаимодействия власти и общества обосновано культурными понятиями порядка, которое отождествляется с легитимным насилием и сильной властью. Тем не менее, как это ни парадоксально, подобные отношения порождают некую враждебность в отношении государства

\footnotetext{
4 Более подробно см.: Тень Грозного царя: Загадки рус. истории / Александр Янов, 218, [5] с. ил. 21 см, М. Изд. фирма «КРУК» 1997.

5 Фурсов А.И, Пивоваров Ю.С. Русская система: генезис, структура, функционирование: (Тезисы и рабочие гипотезы) // Русский исторический журнал. 1998. - Т.1. - № 3. с 87-117.
}

и его неприятия практически на каждом периоде исторического развития.

Понимание процессуальной сущности «русской власти» должно начинаться с исследования ее исходного концепта, зарождения в общественно-политической мысли в России дискурса. Исследуя взгляды отечественных ученых на русскую власть конца XIX века, можно выделить несколько противоположных точек зрения, и, как следствие, несколько мировоззренческих позиций.

Консервативный лагерь, в котором условно присутствует идея «самодержавничества». Данное направление на первоначальном этапе активно развивал Н.М. Карамзин, провозглашая: «Более мудрость охранительная, нежели творческая, что для твердости бытия государственного безопаснее порабощать людей, нежели дать им не вовремя свободу», самодержавие для Н.М.Карамзина - это «палладиум» России, гарант единства и благополучия народа. Истинный патриотизм по Н.М.Карамзину, обязывает гражданина любить свое отечество, невзирая на заблуждения последнего. ${ }^{6}$ В мировоззренческом лагере консерваторов можно выделить общественный идеал славянофилов, стремящийся обосновать национальную идентичность и особость «русского пути». Например, «русский византизм» К.Н. Леонтьева ${ }^{7}$ с провозглашением «самодержавия, православия, народности» официальный монархизм С.С. Уварова и другие ${ }^{8}$. Основными идеями консерватизма в России всегда были государственная целостность, национальное единство, сильная власть, религиозность, патриотизм.

Различные течения революционного радикализма, представляют собой второй мировоззренческий лагерь. Особенный подъем революционных настроений можно наблюдать в периоды контрреформ. Что является естественной реакцией общества на подобную политику правительства, а также отражением своеобразного цикла в политической истории страны. Основными идеями революционного ради-

\footnotetext{
6 Карамзин Н.М. История государства Российского т.3. - М.: Издательство, 2008г. - 768c.

7 Более подробно см.: Бердяев Н.А. Константин Леонтьев. Очерк из истории русской религиозной мысли // Бердяев Н.А. Константин Леонтьев. Очерк из истории русской религиозной мысли. Алексей Степанович Хомяков. - М.: АСТ: АСТ МОСКВА: ХРАНИТЕЛЬ, 2007.

8 Более подробно см.: Парсамов В. С., Удалов С.В. Сергей Семёнович Уваров // Уваров С.С. Избранные труды. - М.: РОССПЭН, 2010.
} 
кализма в начале XIX века в России стали идеи декабристов, революционного демократизма 40-60-х гг. и народничества, идейным вдохновителем которого стал П.Н. Ткачев ${ }^{9}$. Позднее - идеи марксизма, развивающиеся в русском варианте в работах П.Б.Струве и Н.А. Бердяева. ${ }^{10}$

К концу XIX века критика по отношению к деспотизму эволюционировала в революционный радикализм, разделяясь первоначально на теории анархизма и тоталитарную концепцию большевизма. Последняя, как показывает исторический опыт, стала самой успешной из всего идейного спектра. Это объясняется тем что, в сознании русского народа с одной стороны всегда существовала дихотомия рабская покорность, терпение, религиозность, коллективизм, а с другой - стремление к анархии, справедливости, свободолюбие, и так далее. Именно идеология большевиков стала соединением такой дихотомии, вершиной парадоксов русской власти, её воплощением. Изменившаяся в корне государственность в начале $\mathrm{XX}$ века по своей сути унаследовала черты прежних режимов, и продолжила традиционные схемы взаимодействия общества и государства. Подобная ситуация может объясняться готовыми схемами социализации с традиционными элементами. И подменой культурной образцов на схожие, в каждом этапе политического развития.

К середине XIX в. в России сформировалось еще одно направление социально-политической мысли - либерализм, отличавшееся от крайних идей консерватизма и идей революционного радикализма своим пристальным вниманием к человеку как личности. Идеи либерализма, нашли отражение в работах философов начала XIX века. Особенные черты русского либерализма того периода можно проследить в работах М.М. Сперанского, который в своих философских произведениях порицал произвол и деспотизм, призывал уважать человеческое достоинство. Новые права обществу, по его мнению, должна даровать власть. ${ }^{11}$

\footnotetext{
9 Более подробно см.: Ткачёв П.Н. Сочинения: в 2 т. - М.: Мысль, 1975-1976. - 2 т. Режим доступа: http://www.runivers. ru/philosophy/lib/book6255/)

10 Более подробно см.: Струве П.Б. Избранные сочинения. М.: Росспэн, 1999. ISBN 5-86004-145-4.

11 Томсинов В. А.«Светило российской бюрократии»: исторический портрет М. М. Сперанского. Москва: Молодая гвардия, 1991 г. 334 с. 5-е издание, обновленное и дополненное. - М.: Зерцало. - М, 2012. 476 с.
}

Либеральное движение в России имело не постоянный характер. Его представители то пытались подтолкнуть монархов к проведению реформ, то искали союзников в стане революционеров. Однако, под влиянием французской революции 1848 г. и поражения России в Крымской войне (1853-1855 гг.), показавшее слабость государственно-крепостнического строя перед капиталистически развивающимися странами, во второй половине XIX в. происходит возрастание активности либеральных движений и, как итог, обострение атак леворадикальных сил России на правительство ${ }^{12}$. В целом, либеральное движение не смогло повлиять на ход политической истории в полной мере, но, тем не менее, его представители стали одними из первых, кто поднимал вопрос об ограничении власти через конституционную монархию и построения в России государства на основе либеральных ценностей.

Таким образом, понятие и научная категория «русская власть» в социально-политической мысли начали формироваться в начале XIX в. Интерес общества к осмыслению этой категории прослеживается вплоть до начала советского периода истории России. Так как большевистская доктрина была победившей идеологией, власть отметала любые научные направления и школы кроме марксисткой, которая считалась на тот момент исчерпывающей в своих объяснениях. Для советских ученых не стоял вопрос о системе власти в России, она была определена марксистко-ленинской теорией.

Либеральная модель каждый раз терпит поражение на русской почве, так как не вписывается в традиционные политические модели русского общества, вызывает недоверие у большей части населения. Политические процессы конца 1980 - начала 1990 гг. способствовали необходимости переосмысления путей развития государства. Всякий раз возврат к теме «русская власть» связан с политическими модернизационными процессами как власти, так и общества в целом. Цикличность в «русской власти» может объясняться особенностями социализации и преимуществом традиционных ценностей в общественной жизни, которые адаптируются каждый раз к новым условиям посредством подмены символических значений.

12 Зайончковский П.А. Российское самодержавие в конце XIX века. - М.: Мысль, 1970. - 449 с. 


\section{Библиография:}

1. Фурсов А.И, Пивоваров Ю.С. Русская система: генезис, структура, функциониро-вание: (Тезисы и рабочие гипотезы) // Русский исторический журнал. 1998. - Т.1. - № 3. с 87-117.

2. Лубский А.А.Концепт «Русская власть» метафорические возможности интеллек-туального дискурса:// Фонд исторической перспективы.2010 [Электронный ресурс]. Режим доступа: http: // www russkayavlast metaforicheskievozmoznostiintellektualnogodiskursa (дата обращения 18.03.2013)

3. Карамзин Н.М. История государства Российского т.3. - М.: Издательство, 2008 г. - 768 с.

4. А. «Светило российской бюрократии»: исторический портрет М. М. Сперанского. Москва: Молодая гвардия, 1991 г. 334 с. 5-е издание, обновленное и дополненное. - М.: Зерцало. --М, 2012. 476 с.

5. Леонтович В. В.История либерализма в России (1762-1914). - М.: Русский путь, 1995. - 444 с.

6. Зайончковский П.А. Российское самодержавие в конце XIX века. - М.: Мысль, 1970. - 449 с.

7. Нилогов А.С.. Этос философии науки (беседа А. С. Нилогова с А. П. Огурцовым в рамках проекта «Кто сегодня делает философию в России») . // Философия и культура. - 2014. - № 7. - С. 992-999. DOI: 10.7256/1999-2793.2014.7.12308

8. Попова А.В.. Русская неолиберальная политико-правовая доктрина как интегральный тип правопонимания в конце XIX - начале XX вв.. // Политика и Общество. - 2014. - № 2. - C. 167-175. DOI: 10.7256/18128696.2014.2.84911.

9. Самохин К.В.. Модернизация Российской империи в начале XX века. // Политика и Общество. - 2014. № 1. - C. 47-60. DOI: 10.7256/1812-8696.2014.1.9442

10. Нилогов А.С.. Этос философии науки (беседа А. С. Нилогова с А. П. Огурцовым в рамках проекта «Кто сегодня делает философию в России») . // Философия и культура. - 2014. - № 7. - С. 992-999. DOI: 10.7256/1999-2793.2014.7.12308

11. Борисенков А.А.. Понятие общественной власти в современной российской конституции. // Право и политика. - 2013. - № 13. - С. 1786-1795. DOI: 10.7256/1811-9018.2013.13.10371

12. Чепус А.В.. Современное состояние российского законодательства о парламентской ответственности в РФ . // Право и политика. - 2013. - № 12. - С. 1665-1671. DOI: 10.7256/1811-9018.2013.12.10214

13. Гончаров В.В.. Государственная власть: понятие и сущность. // Политика и Общество. - 2013. - № 7. C. 817-825. DOI: $10.7256 / 1812-8696.2013 .7 .2466$

14. И. В. Кондаков. «Новая Русь» и судьба человечества: русская культура в концепции Л. Н. Гумилева. // Культура и искусство. - 2013. - № 1. - С. 7-20. DOI: 10.7256/2222-1956.2013.01.1

15. Н. В. Филина. Сотрудничество государственных институтов и религиозных организаций в современной России. // Право и политика. - 2012. - № 6. - С. 1026-1039.

16. И. Д. Короева. Философия взаимодействия власти и народа. // Политика и Общество. - 2012. - № 4. С. $18-24$.

17. И.Н. Сиземская. Русская интеллигенция и власть. // Философия и культура. - 2011. - № 6. - С. 39-47.

18. Г.В.Мальцев. О распределении власти в обществе. // Политика и Общество. -2009 . - № 10.

19. 3.М. Муртазалиев. Особенности реализации политической власти в условиях глобализации.. // Право и политика. - 2009. - № 4

\section{References:}

1. Fursov A.I, Pivovarov Yu.S. Russkaya sistema: genezis, struktura, funktsioniro-vanie: (Tezisy i rabochie gipotezy) // Russkii istoricheskii zhurnal. 1998. - T.1. - № 3. s 87-117.

2. Lubskii A.A.Kontsept «Russkaya vlast'» metaforicheskie vozmozhnosti intellek-tual'nogo diskursa://Fond istoricheskoi perspektivy.2010 [Elektronnyi resurs]. Rezhim dostupa: http: // www russkayavlastmetaforicheski evozmoznostiintellektualnogodiskursa (data obrashcheniya 18.03.2013)

3. Karamzin N.M. Istoriya gosudarstva Rossiiskogo t.3. - M.: Izdatel'stvo, 2008g. - 768s.

4. A. «Svetilo rossiiskoi byurokratii»: istoricheskii portret M. M. Speranskogo. Moskva: Molodaya gvardiya, 1991 g. 334 s. 5-e izdanie, obnovlennoe i dopolnennoe. - M.: Zertsalo. --M, 2012. 476 s. 
DOI: $10.7256 / 2073-8560.2014 .4 .12838$

При цитировании этой статьи сноска на dоі обязательна

\section{Национальная безопасность - № 4(33) • 2014}

5. Leontovich V. V.Istoriya liberalizma v Rossii (1762-1914). - M.: Russkii put', 1995. - $444 \mathrm{~s}$.

6. Zaionchkovskii P.A. Rossiiskoe samoderzhavie v kontse XIX veka. - M.: Mysl', 1970. -449 s.

7. Nilogov A.S.. Etos filosofii nauki (beseda A. S. Nilogova s A. P. Ogurtsovym v ramkakh proekta «Kto segodnya delaet filosofiyu v Rossii»)) . / Filosofiya i kul'tura. - 2014. - № 7. - S. 992-999. DOI: 10.7256/1999-2793.2014.7.12308

8. Popova A.V.. Russkaya neoliberal'naya politiko-pravovaya doktrina kak integral'nyi tip pravoponimaniya v kontse XIX - nachale XX vv.. // Politika i Obshchestvo. - 2014. - № 2. - S. 167-175. DOI: 10.7256/1812-8696.2014.2.84911.

9. Samokhin K.V.. Modernizatsiya Rossiiskoi imperii v nachale KhKh veka. // Politika i Obshchestvo. - 2014. № 1. - S. 47-60. DOI: 10.7256/1812-8696.2014.1.9442

10. Nilogov A.S.. Etos filosofii nauki (beseda A. S. Nilogova s A. P. Ogurtsovym v ramkakh proekta «Kto segodnya delaet filosofiyu v Rossii») . // Filosofiya i kul'tura. - 2014. - № 7. - S. 992-999. DOI: 10.7256/1999-2793.2014.7.12308

11. Borisenkov A.A.. Ponyatie obshchestvennoi vlasti v sovremennoi rossiiskoi konstitutsii. // Pravo i politika. - 2013.№ 13. - S. 1786-1795. DOI: 10.7256/1811-9018.2013.13.10371

12. Chepus A.V.. Sovremennoe sostoyanie rossiiskogo zakonodatel'stva o parlamentskoi otvetstvennosti v RF . // Pravo i politika. - 2013. - № 12. - S. 1665-1671. DOI: 10.7256/1811-9018.2013.12.10214

13. Goncharov V.V.. Gosudarstvennaya vlast’: ponyatie i sushchnost'. // Politika i Obshchestvo. - 2013. - № 7. S. 817-825. DOI: 10.7256/1812-8696.2013.7.2466

14. I. V. Kondakov. «Novaya Rus'» i sud'ba chelovechestva: russkaya kul'tura v kontseptsii L. N. Gumileva. // Kul'tura i iskusstvo. -2013 . - № 1. - S. 7-20. DOI: 10.7256/2222-1956.2013.01.1

15. N. V. Filina. Sotrudnichestvo gosudarstvennykh institutov i religioznykh organizatsii v sovremennoi Rossii. // Pravo i politika. - 2012. - № 6. - S. 1026-1039.

16. I. D. Koroeva. Filosofiya vzaimodeistviya vlasti i naroda. // Politika i Obshchestvo. - 2012. - № 4. - S. 18-24.

17. I.N. Sizemskaya. Russkaya intelligentsiya i vlast'. // Filosofiya i kul'tura. - 2011. - № 6. - S. 39-47.

18. G.V.Mal’tsev. O raspredelenii vlasti v obshchestve. // Politika i Obshchestvo. - 2009. - № 10.

19. Z.M. Murtazaliev. Osobennosti realizatsii politicheskoi vlasti v usloviyakh globalizatsii.. // Pravo i politika. 2009. - № 4. 